\title{
Human remains in society
}

Curation and exhibition in the aftermath of genocide and mass-violence

Edited by JEAN-MARC DREYFUS

and ÉLISABETH ANSTETT

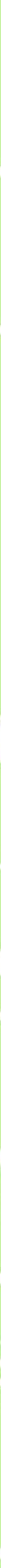


Jean-Marc Dreyfus and Élisabeth Anstett - 9781526129338 Downloaded from manchesterhive.com at $04 / 26 / 2023$ 08:57:33AM 


\section{Human remains in society}

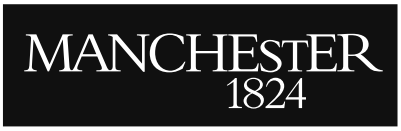

Manchester University Press 


\section{HUMAN REMAINS AND VIOLENCE}

Human remains and violence aims to question the social legacy of mass violence by studying how different societies have coped with the dead bodies resulting from war, genocide and state sponsored brutality. However, rather paradoxically, given the large volume of work devoted to the body on the one hand, and to mass violence on the other, the question of the body in the context of mass violence remains a largely unexplored area and even an academic blind spot. Interdisciplinary in nature, Human remains and violence intends to show how various social and cultural treatments of the dead body simultaneously challenge common representations, legal practices and morality. This series aims to provide proper intellectual and theoretical tools for a better understanding of mass violence's aftermaths.

\section{Series editors}

Élisabeth Anstett and Jean-Marc Dreyfus

\section{ALSO AVAILABLE IN THIS SERIES}

Destruction and human remains: disposal and concealment in genocide and mass violence

Edited by Élisabeth Anstett and Jean-Marc Dreyfus

Human remains and mass violence: methodological approaches Edited by Jean-Marc Dreyfus and Élisabeth Anstett

Governing the dead: sovereignty and the politics of dead bodies Finn Stepputat 


\section{Human remains in society}

Curation and exhibition in the aftermath of genocide and mass-violence

Edited by Jean-Marc Dreyfus and Élisabeth Anstett

Manchester University Press 
While copyright in the volume as a whole is vested in Manchester University Press, copyright in individual chapters belongs to their respective authors.

This electronic version has been made freely available under a Creative Commons (CC-BY-NC-ND) licence, which permits non-commercial use, distribution and reproduction provided the author(s) and Manchester University Press are fully cited and no modifications or adaptations are made. Details of the licence can be viewed at https://creativecommons.org/licenses/by-nc-nd/3.0/

Published by Manchester University Press

Altrincham Street, Manchester M1 7JA

www.manchesteruniversitypress.co.uk

British Library Cataloguing-in-Publication Data

A catalogue record for this book is available from the British Library

Library of Congress Cataloging-in-Publication Data applied for

ISBN 9781526107381 hardback

First published 2017

The publisher has no responsibility for the persistence or accuracy of URLs for any external or third-party internet websites referred to in this book, and does not guarantee that any content on such websites is, or will remain, accurate or appropriate.

Typeset in Minion

by Out of House Publishing

Printed in Great Britain

by CPI Group (UK) Ltd, Croydon, CR0 4YY 